\title{
Des magdaléniens du bassin parisien aux dolganes du Taïmyr
}

Francine David, Vladimir I. Diachenko, Claudine Karlin et Youri Tchesnokov

\section{(2) OpenEdition}

1 Journals

Édition électronique

URL : https://journals.openedition.org/tc/423

DOI : $10.4000 /$ tc. 423

ISSN : 1952-420X

Éditeur

Éditions de l'EHESS

Édition imprimée

Date de publication : 1 octobre 1998

ISSN : 0248-6016

\section{Référence électronique}

Francine David, Vladimir I. Diachenko, Claudine Karlin et Youri Tchesnokov, « Des magdaléniens du bassin parisien aux dolganes du Taïmyr », Techniques \& Culture [En ligne], $30 \mid$ 1998, mis en ligne le 28 octobre 2005, consulté le 29 septembre 2022. URL : http://journals.openedition.org/tc/423; DOI : https://doi.org/10.4000/tc.423

Ce document a été généré automatiquement le 29 septembre 2022.

Tous droits réservés 


\section{Des magdaléniens du bassin parisien aux dolganes du Taïmyr}

Francine David, Vladimir I. Diachenko, Claudine Karlin et Youri Tchesnokov 